\title{
RELATIONSHIP BETWEEN PROSTHODONTIC TREATMENT AND NUTRITIONAL STATUS: A REVIEW
}

\author{
Basnet $B B^{1 *}$, Limbu $L K^{1}$, Alhajj $M N^{2}$, Rokaya $D^{3}$
}

\section{Affiliation}

1. Assistant Professor, Department of Prosthodontics, Crown Bridge. B.P. Koirala Institute of Health Sciences, Dharan, Nepal

2. Lecturer, Department of Prosthodontics, Faculty of Dentistry, Thamar University, Dhamar Yemen.

3. PhD Scholar, Dental Biomaterial Science, Faculty of Dentistry, Chulalongkorn University, Bangkok, Thailand.

\section{ARTICLE INFO}

Article History

Received : 5 February, 2018

Accepted : 17 April, 2018

Published : 30 April, 2018

(C) Authors retain copyright and grant the journal right of first publication with the work simultaneously licensed under Creative Commons Attribution License CC - BY 4.0 that allows others to share the work with an acknowledgment of the work's authorship and initial publication in this journal.

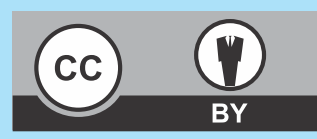

RA 1

DOI: http://dx.doi.org/10.3126/bjhs.v3i1.19768

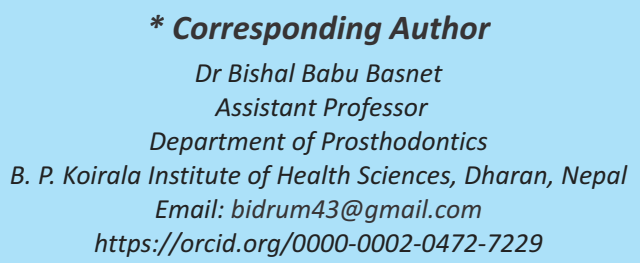

\section{Citation}

Basnet BB, Limbu LK, Alhajj MN, Rokaya D. Relationship Between Prosthodontic Treatment and Nutritional Status: A Review. BJHS 2018;3(1)5:385- 389.

\begin{abstract}
Pertinent literature search about changes or effects of prosthodontic treatment on nutritional status was performed. The articles were electronically and hand searched in all available journals Including research works, reviews, randomized controlled trials and systematic reviews. The information were obtained to answer the question whether denture therapy has a role in altering nutritional intake or not. Most articles agreed that the risk of malnutrition is elevated by being edentulous. However, there were contrasting results about improvement of nutrition by providing prosthodontic treatment. Thus, many authors have emphasized the role of nutritional counseling along with denture therapy for the benefits of geriatric patients who undergo the inevitable process of being edentulous.
\end{abstract}

\section{KEYWORDS}

Denture prosthesis, mini nutrition assessment, nutritional status 


\section{INTRODUCTION}

Prosthodontics is defined as the specialty replacing missing dentition and contiguous maxillofacial structures. ${ }^{1}$ Prosthodontic treatment not only replaces form, functions and esthetics in orofacial region but also enhances the psychological and social levels of dentally handicapped individuals. The oral health is an important entity of general health. Terming it as the fundamental factor, World Health organization (WHO) emphasizes on oral and dental health maintenance throughout life for improving quality of life. ${ }^{2}$ Older people are vulnerable to restrict their diet. Significant increase in dietary intake of lipids, carbohydrates and fibers is seen in fully dentate individuals in comparison to complete denture wearers. ${ }^{3}$

Oral rehabilitation is one of the methods to replenish malnutrition. ${ }^{4,5}$ There are clear evidences that edentulism is associated with poor diet, compromised nutrition and also lower level of subjective well-being. ${ }^{6,7}$

The literature search was performed electronically and also hand searched with the terms, using Medical Subject Headings (MeSH) and free text words. The words used were "nutritional status", "nutrition", "mini-nutritional assessment", "denture therapy", "removable prosthodontic treatment", "fixed prosthodontic treatment", "implant therapy". The search was limited to only English articles. The reference lists of identified articles and relevant papers were also be assessed. The Cochrane database, Medline and Google were used for collecting the articles. The search strategy is depicted in flow diagram (figure 1)

\section{Measurement of nutritional status}

Mini nutritional assessment (MNA) was used by many authors to test and evaluate nutritional aspect in prosthodontic patients and was found to be a valid and sensitive tool. ${ }^{1,8-11}$ Oral health impact profile (OHIP), oral health related quality of life (OHRQoL), closed-ended questionnaire and chewing efficiency were also used to determine the level of nutritional status. ${ }^{4,12,13}$

\section{Effects of being edentulous}

Dental status greatly influences the perceived ability to take number of foods and having few teeth (less than 21 teeth) or no teeth without replacement increases vulnerability to malnutrition. ${ }^{14}$

Poor oral hygiene can increase the difficulty in eating hard foods and thus, decreases eating pleasure. ${ }^{15}$ When comparing fully dentate to fixed prosthesis wearers, higher level of energy, protein, fat, carbohydrate, calcium, phosphorus and thiamin was consumed by fully dentate group while, other foods rich in fiber and electrolyte did not have significant difference. ${ }^{16}$

Totally edentulous patients without dentures are vulnerable to malnutrition. ${ }^{5}$ Twenty-four hour dietary intake showed that mastication, chewing and food choice can be influenced by dentulousness and quality of denture. ${ }^{7}$

Poorest nutritional status was reported in edentulous patients without dentures, whereas edentulous patients

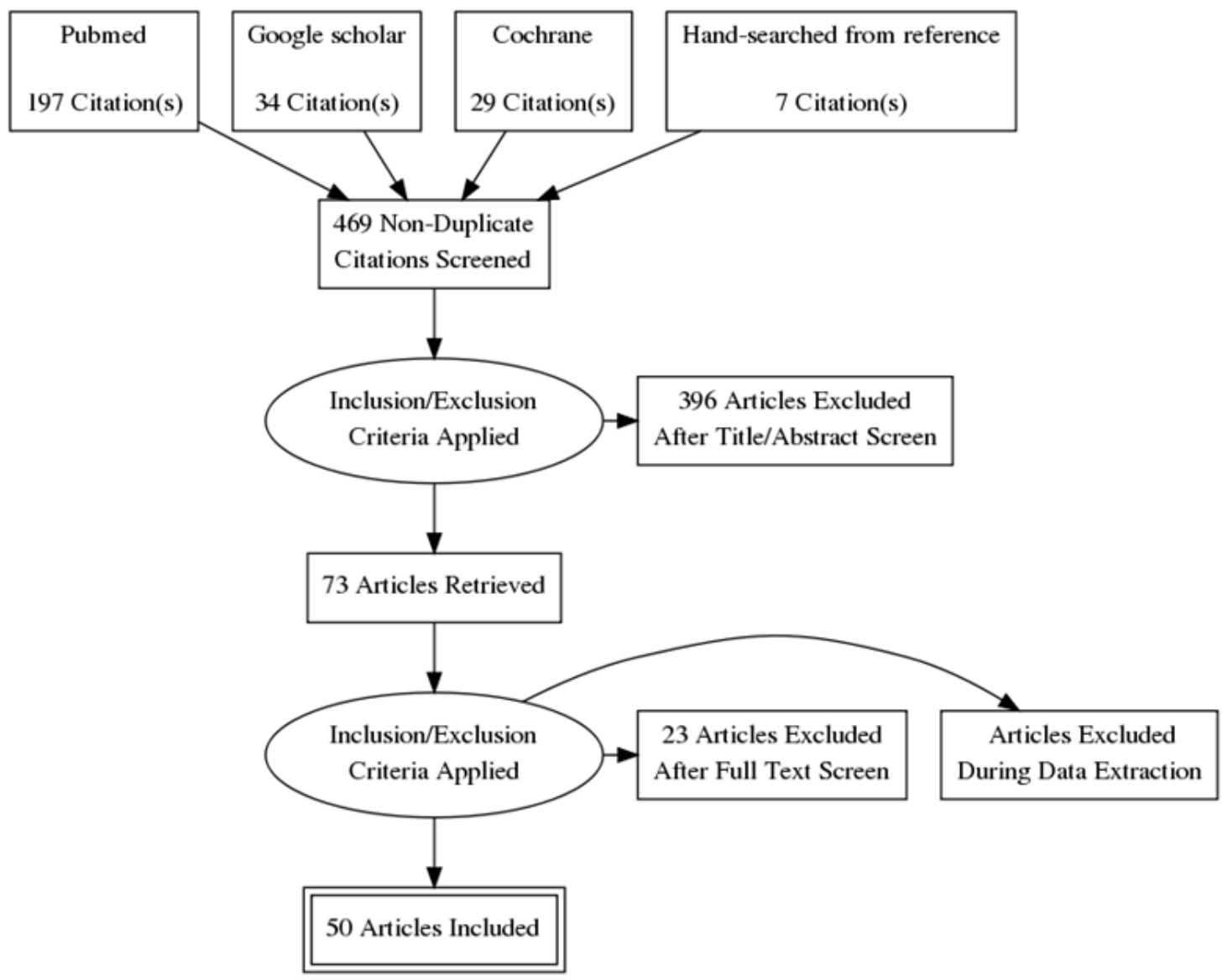

Figure 1: Search strategy used in this review 
with denturescan consume the recommended energy and micronutrients. ${ }^{17}$ In contrast, another study revealed that the elevated Body Mass Index (BMI) due to eating highcalorie selected foods, was found in edentulous patients. ${ }^{18}$

\section{Effects of prosthodontic treatment}

According to a study conducted in a sample size of 35 patients, food consumption behavior was not affected by prosthodontic therapy as provision of complete denture had reduced the chewing difficulties but didn't have a role in reduction of malnutrition. ${ }^{14}$ Another follow-up study suggested that prosthetic treatment alone is not sufficient to provide an improvement in MNA, serum parameters, OHIP and masticatory efficiency test. ${ }^{13}$ Consistent with these studies, the other also did not find correlation with any prostheses to the prosthodontic treatment. ${ }^{19,20}$

Though masticatory function was seen to be improved in new denture users but there was no significant difference where both the new denture and old denture users had almost $100 \%$ of total intake of energy and nutrition. ${ }^{21}$ Choice of food (food rich in fat, micronutrients, hard to chew food) was also affected by denture replacement. However, total energy intake, anthropometry and biochemical indices experienced no significant impact. ${ }^{22}$

It was also found that prosthetic treatment improves nutritional status as higher MNA was reported in edentulous patients after treatment with complete dentures. $^{23,24}$

Kikutani et al examined a group of 716 elderly patientswith the use of MNA-SF and Barthel index to evaluate nutrition. ${ }^{25}$ It was concluded that occlusal status was significantly related to malnutrition risk. The limited daily activity was sorted as a confounding factor.

Another comparative study showed that presence of few teeth in the oral cavity was associated with lower intake of fish and fruits, lower BMI, low mid arm circumference (MAC), low serum albumin in non-denture wearers. After denture replacement, only MAC was significantly associated with denture therapy. However, in participants who had both fewer teeth and no dentures, marked decrease of nutritional intake was observed. ${ }^{26}$ Sadamori et al. divided their study sample into five groups and studied for two years taking the anthropometric and biochemical parameters. They concluded that it is necessary to have prosthodontic treatment for long-term maintenance of calorie intake. However, their study was focused in the people with dementia. ${ }^{27}$

Compared to denture wearers, non-denture wearers were found to have lower phosphorus, iron, potassium, niacin and Vitamin C intake. ${ }^{28}$ Contrasting reports were also found making the role of prosthodontic therapy questionable in improvement of nutrition. . $^{32,30}$

In comparing various types of dental prostheses, implant therapy was shown to be beneficial for improving nutritional status. ${ }^{12,16,31-34}$ Removable prostheses, however, were reported to have less contribution than fixed prostheses for subjective improvement in nutritional status. ${ }^{35}$ In contrast, a study was done in a group of 135 patients divided into four groups; Complete denture $(C D)$, distalextension removable partial denture (RPD); toothsupported RPD and fixed partial denture (FPD) showed significant improvement of BMI and energy intake in $\mathrm{CD}$ groups.In this study, removable prostheses had better results in terms of protein, carbohydrate, calorie, iron and vitamin B. However, serum albumin increased in all groups. ${ }^{36}$ RPD wearers were less capable for deriving nutrition in terms of mixing and shaping the bolus, and number of strokes while, level of fat, calcium and BMI were almost similar in removable partial dentures and fixed dentures wearers. ${ }^{37}$

Some other cross-sectional studies showed contrast results to the findings of the previous studies and concluded that dental implant does not necessarily improve the nutritional status, however can improve masticatory efficiency. ${ }^{12,31,38}$

Randomized controlled trials for comparing conventional $C D$ and implant overdenture (IOD) showed insignificant improvement in nutritional status by implant over denture, however IOD wearers had improvement if we considered fiber intake. $^{39-41}$

Another systematic review and meta-analysis also concluded insignificant benefits of implant overdenture over the conventional complete denture in terms of BMI, albumin or vitamin $\mathrm{B}^{12,42}$

\section{Other factors}

Several authors have emphasized on nutritional counseling as a part to improve nutrition along with prosthodontic therapy because denture alone was not the only factor for better nutrition in their studies. ${ }^{19,39,43-46}$

In denture wearing patients, changing to new dentures along with periodic counseling played an important role in increasing levels of energy, iron and vitamin C intake. ${ }^{43}$

With the use of denture adhesive improvement in taking vegetables, fruits was seen. ${ }^{44}$ But the reinforcement with nutritional counseling was also done during adhesive provision.

Influence of number of artificial teeth in complete denture was also tested in a randomized controlled trial, which showed no significance of removing or adding the second molar artificial teeth. ${ }^{47}$ Shortened dental arch was studied to assess the impact on nutrition, which showed objective improvement despite insignificant subjective perception. ${ }^{48}$

One month after prosthodontic treatment, MNA and hematological parameters were measured in a randomized controlled trial.This study comprised conventional and functionally orientated dentures in partially dentate groups.The results showed increase in vitamin B12, albumin, and MNA. ${ }^{49}$

Despite the denture therapy, some studies concluded that lack of appetite or limited daily activity play as confounding factors along with poor oral status and/or prosthetic status. ${ }^{25,50}$

\section{CONCLUSIONS}

A review of various literature regarding nutritional status in prosthodontic patients was done in this study. Emphasis was drawn to the studies which had objectively assessed the role 
of denture (fixed, removable or implant-supported) in improving nutritional status. Also, randomized controlled trials and systematic reviews were further analyzed to draw the inference. It was common finding that the nutrition is affected by edentulism and, hence, early prosthodontic rehabilitation has some role in decreasing the vulnerability to malnutrition. However, the mere provision of denture therapy alone cannot replenish the nutrition. Periodic counseling plays a vital role for the reduction of malnutrition risk in elderly patients.

\section{RECOMMENDATIONS}

\section{The studies on nutritional assessment after various}

\section{REFERENCES}

1. The glossary of prosthodontic terms:Ninth Edition. J Prosthet Dent. 2017;117:e1-105.PMID: 28418832

2. World congress-2015."Dental care and oral health for healthy longevity in an aging society." [Internet] Available from: http:// www.who. int/oral_health/tokyodeclaration_final.pdf?ua=1 [Cited:April 24, 2018]

3. Cousson PY, Bessadet M, Nicolas E, Veyrune JL, Lesourd B, Lassauzay C. Nutritional status, dietary intake and oral quality of life in elderly complete denture wearers. Gerodontology. 2012;29 (2):e685-92.PMID: 22004061

4. Hutton B, Feine J, Morais J. Is there an association between edentulism and nutritional state? J Can Dent Assoc. 2002;68(3): 182-7. PMID: 11911815

5. De Marchi RJ, Hugo FN, Hilgert JB, Padilha DM. Association between oral health status and nutritional status in south Brazilian independent-living older people. Nutrition. 2008;24(6):54653.PMID: 18455655

6. Hewlett SA, Yawson AE, Calys-Tagoe BN, Naidoo N, Martey P, Chatterji $S$ et al. Edentulism and quality of life among older Ghanaian adults.BMC Oral Health. 2015;15:48.PMID:25886750

7. Lin YC, Chen JH, Lee HE, Yang NP, Chou JM. The association of chewing ability and diet in elderly complete denture patients. Int J Prosthodont. 2010;23:127-8.PMID: 20305849

8. Guigoz Y. The Mini Nutritional Assessment (MNA) review of the literature--what does it tell us? J Nutr Health Aging. 2006;10:46685; discussion 485-7.PMID: 17183419

9. Brownie S. Why are elderly individuals at risk of nutritional deficiency? Int J NursPract. 2006;12:110-8. PMID: 16529597

10. Soini H, Muurinen S, Routasalo P, Sandelin E, Savikko N, Suominen $M$ et al. Oral and nutritional status-Is the MNA a useful tool for dental clinics. J Nutr Health Aging. 2006;10:495-9; discussion 5001.PMID: 17183421

11. Kaiser M, Bauer JM, Ramsch C, Uter W, Guigoz Y, Cederholm T, et al. Validation of the mini nutritional assessment short-form $\left(\mathrm{MNA}^{{ }}{ }_{\text {- }}\right.$ SF): a practical tool for identification of nutritional status. J Nutr Health Aging. 2009;13(9):782-8.PMID: 19812868

12. Boven GC, Raghoebar GM, Vissink A, Meijer HJA. Improving masticatory performance, bite force, nutritional state and patient's satisfaction with implant overdentures: a systematic review of the literature. J Oral Rehabil. 2015;42(3):220-3. PMID:25307515

13. Wöstmann B, Michel K, Brinkert B, Melchheier-Weskott A, Rehmann P, Balkenhol M. Influence of denture improvement on the nutritional status and quality of life of geriatric patients. J Dent. 2008;36(10):816-21.PMID: 18603344

14. Marcenes W, Steele JG, Sheiham A, Walls AWG. The relationship between dental status, food selection, nutrient intake, nutritional status, and body mass index in older people. Cad Saude Publica. 2003;19(3):809-15.PMID: 12806483 prosthodontic treatment is being done globally, however, very few studies are found in our parts of world. While the modern treatment like implant therapy has been found to be great boon for improvement of nutritional status according to these studies, conventional therapies like removable partial denture, fixed partial denture and conventional complete denture cannot be overlooked. Thus, it is recommended that more studies regarding the effects of conventional denture therapies need to be done and especially in the less developed regions of world.
15. Lamy M, Mojon P, Kalykakis G, Legrand R, Butz-Jorgensen E. Oral status and nutrition in the institutionalized elderly. J Dent. 1999;27(6):443-8.PMID: 10399411

16. Choi Y, Park D, Kim Y. Relationship between prosthodontic status and nutritional intake in the elderly in Korea: National health and nutrition examination survey (NHANES IV). Int J Dent Hyg. 2014;12(4):285-90.PMID: 24354919

17. Saarela RKT, Lindroos E, Soini H, Hiltunen K, Muurinen S, Suominen $\mathrm{MH}$, et al. Dentition, nutritional status and adequacy of dietary intake among older residents in assisted living facilities. Gerodontology. 2016;33(2):225-32. PMID: 25163661

18. Sahyoun NR, Lin CL, Krall E. Nutritional status of the older adult is associated with dentition status. JAm Diet Assoc. 2003;103:61-6. PMID: 12525795

19. Sebring NG, Gucks AD, Li SH, McCarthy GR. Nutritional adequacy of reported intake of edentulous subjects treated with new conventional or implant supported mandibular dentures. J Prosthet Dent. 1995;74:358-63.PMID: 8531152

20. Sandstrom B, Lindquist LW. The effects of different prosthetic restorations on the dietary selection in edentulous patients. A longitudinal study of patients initially treated with optimal complete dentures and finally with tissue integrated prostheses. Acta Odontol Scand. 1987;45:423-8.PMID: 3324624

21. Allen PF. Association between diet, social resources and oral health related quality of life in edentulous patients. J Oral Rehabil. 2005;32(9):623-8.PMID: 16102073

22. Gunji A, Kimoto S, Koide H, Murakami H, Matsumaru Y, Kimoto K, et al. Investigation on how renewal of complete dentures impact on dietary and nutrient adequacy in edentulous patients. J Prosthodont Res. 2009;53(4):180-4.PMID: 19589745

23. Lee JS, Weyant RJ, Corby P, Kritchevsky SB, Harris TB, Rooks R, et al. Edentulism and nutritional status in a biracial sample of wellfunctioning, community-dwelling elderly: the health, aging and body composition study. Am J Clin Nutr. 2004;79:295-302.PMID: 14749237

24. Prakash N, Kalavathy N, Sridevi J, Premnath K. Nutritional status assessment in complete denture wearers. Gerodontology. 2012;29(3):224-30.PMID: 22512332

25. Kikutani T, Yoshida M, Enoki H, Yamashita Y, Akifusa S, Shimazaki Y, et al. Relationship between nutrition status and dental occlusion in community-dwelling frail elderly people: nutrition status and dental occlusion. Geriatr Gerontol Int. 2013;13(1):50-4.PMID: 22489562

26. Kim JM, Stewart R, Prince M, Kim SW, Yang SJ, Shin IS, et al. Dental health, nutritional status and recent-onset dementia in a Korean community population. Int J Geriatr Psychiatry. 2007;22(9):850-5.PMID: 17266172

27. Sadamori S, Hayashi S, Fujihara I, Abekura H, Hamada T, Akagawa Y. Nutritional status and oral status of the elderly with dementia: a two-year study. Gerodontology. 2012;29:e756-60. PMID: 21910747 
28. Han SY, Kim CS. Does denture-wearing status in edentulous South Korean elderly persons affect their nutritional intakes? Gerodontology. 2016;33(2):169-76.PMID: 24641726

29. Shinkai RS, Hatch JP, Rugh JD, Sakai S, Mobley CC, Saunders MJ. Dietary intake in edentulous subjects with good and poor quality complete dentures. J Prosthet Dent. 2002;87(5):490-8.PMID: 12070511

30. Yoshida M, Suzuki R, Kikutani T. Nutrition and oral status in elderly people. Jpn Dent Sci Rev. 2014;50:9-14.DOI: 10.1016/j.jdsr. 2013.09.001

31. De Oliveira TR, Frigerio ML. Association between nutrition and the prosthetic condition in edentulous elderly. Gerodontology. 2004;21:205-8.PMID: 15603279

32. Tajbakhsh S, Rubenstein JE, Faine MP, Mancl LA, Raigrodski AJ. Selection patterns of dietary foods in edentulous participants rehabilitated with maxillary complete dentures opposed by mandibular implantsupported prostheses: a multicenter longitudinal assessment. J Prosthet Dent. 2013;110(4):252-8.PMID: 24079559

33. Allen F, McMillan A. Food selection and perceptions of chewing ability following provision of implant and conventional prostheses in complete denture wearers. Clin Oral Impl Res. 2002;13:320-6. DOI: $10.1034 / \mathrm{j} .1600-0501.2002 .130313 . x$

34. Morais JA, Heydecke G, Pawliuk J, Lund JP, Feine JS. The effects of mandibular two-implant overdentures on nutrition in elderly edentulous individuals. J Dent Res. 2003;82(1):53-8.PMID: 12508046

35. Tsai AC, Chang TL. Association of dental prosthetic condition with food consumption and the risk of malnutrition and follow-up 4year mortality risk in elderly Taiwanese. J Nutr Health Aging. 2011;15:265-70. PMID: 21437557

36. Goel K, Singh SV, Chand P, Rao J, Tripathi S, Kumar L, et al. Impact of different prosthodontic treatment modalities on nutritional parameters of elderly patients: nutritional parameters. J Prosthodont. 2016;25(1):21-7.PMID: 25898981

37. Liedberg B, Norlen P, Owall B, Stoltze K. Masticatory and nutritional aspects on fixed and removable partial dentures. Clin Oral Investig. 2004;8(1):11-7.PMID: 15029484

38. Muller K, Morais J, Feine J. Nutritional and anthropometric analysis of edentulous patients wearing implant overdentures or conventional dentures. Braz Dent J. 2008;19(2):145-50.PMID: 18568230

39. Hamada MO, Garrett NR, Roumanas ED, Kapur KK, Freymiller E, Han T, et al. A randomized clinical trial comparing the efficacy of mandibular implant-supported overdentures and conventional dentures in diabetic patients. Part IV: Comparisons of dietary intake. J Prosthet Dent. 2001;85(1):53-60.DOI: 10.1016/S00223913(98)70177-5
40. Müller F, Duvernay E, Loup A, Vazquez L, Herrmann FR, Schimmel M. Implant- supported mandibular overdentures in very old adults: a randomized controlled trial. J Dent Res. 2013;92:154S-60S.PMID: 24158342

41. Hamdan NM, Gray-Donald K, Awad MA, Johnson-Down L, Wollin S, Feine JS. Do implant overdentures improve dietary intake? a randomized clinical trial.J Dent Res. 2013;92:146S-53S.PMID: 24158342

42. Yamazaki T, Martiniuk ALC, Irie K, Sokejima S, Lee CMY. Does a mandibular overdenture improve nutrient intake and markers of nutritional status better than conventional complete denture? A systematic review and meta-analysis. BMJ Open. 2016;6:e011799. DOI: 10.1136/bmjopen-2016-011799

43. Paturu R, ThallamVeeravalli $P$, Vaidyanathan AK, Grover M. Evaluation of nutritional status and eating pattern in first and secondtime denture wearers: a prospective 60 days ( 2 months) pilot study. J Indian Prosthodont Soc. 2011;11(3):156-64.PMID: 22942575

44. Bartlett DW, Maggio B, Targett D, Fenlon MR, Thomas J. A preliminary investigation into the use of denture adhesives combined with dietary advice to improve diets in complete denture wearers. J Dent. 2013;41(2):143-7.PMID: 23123497

45. Bradbury J, Thomason JM, Jepson NJ, Walls AW, Allen PF, Moynihan PJ. Nutrition counseling increases fruit and vegetable intake in the edentulous. J Dent Res. 2006;85:463-8.PMID: 16632762

46. N'gom PI, Woda A. Influence of impaired mastication on nutrition. J Prosthet Dent. 2002;87:667-73. PMID: 12131890

47. Iegami CM, Barbosa WF, Furuyama RJ, Lima JRB, de Campos TT, Minagi $S$, et al. Masticatory efficiency in complete denture wearers with reduced dental arches - a randomised cross-over study. J Oral Rehabil. 2014;41(8):619-23.PMID: 24779746

48. Fueki K, Igarashi Y, Maeda Y, Baba K, Koyano K, Sasaki K, et al. Effect of prosthetic restoration on masticatory function in patients with shortened dental arches: a multicentre study. J Oral Rehabil. 2016;43(7):534-42. PMID: 26854877

49. McKenna G, Allen PF, Flynn A, O'Mahony D, DaMata C, Cronin M, et al. Impact of tooth replacement strategies on the nutritional status of partially-dentate elders: impact of tooth replacement on nutrition. Gerodontology. 2012;29(2):e883-90. PMID: 22117892

50. Dormenval V, Mojon P, Budtz-Jørgensen E. Associations between self-assessed masticatory ability, nutritional status, prosthetic status and salivary flow rate in hospitalized elders. Oral Dis. 1999;5(1):32-8.PMID: 10218039 